Pakistan Journal of Social Sciences 16(1): 14-29, 2019

ISSN: $1683-8831$

(C) Medwell Journals, 2019

\title{
Employee's Innovative Behaviour: Evidence from Hospitality Industry
}

\author{
${ }^{1}$ Nasser A.O.M. Alareefi, ${ }^{1}$ Abuelhassan E. Abuelhassan, ${ }^{2}$ Gamal S.A. Khalifa, \\ ${ }^{1}$ Mohammed Nusari and ${ }^{1}$ Ali Ameen \\ ${ }^{1}$ Faculty of Business and Accountancy, Lincoln University College (LUC), Selangor, Malaysia \\ ${ }^{2}$ Faculty of Tourism and Hotels, Fayoum University, Faiyum, Egypt
}

\begin{abstract}
Drawing on leadership theory and social exchange theory, the study investigated the role of Perceived Supervisor Support (PSS), Leader-Member Exchange (LMX) and Supervisor Trust (ST) on Employee Innovative Behavior (EIB) in the Dubai's five star hotels. The current study adopted SEM to test the study's hypothesis. A sample of 504 employees in the Dubai's hotels was selected randomly. In this representative sample, a survey was carried out to find out the extent of PSS, ST and LMX influence on EIB. All the study's hypothesis were supported. PSS, ST and LMX significantly predict employee innovative behavior. The proposed model explained $34.7 \%$ of the variance in employee innovative behavior. Finally, theoretical and managerial implications were discussed.
\end{abstract}

Key words: Supervisor support, employee innovative behaviour, supervisor trust, leader-member exchange, UAE, implications

\section{INTRODUCTION}

"Due to the global recession, tourism has stagnated and the hospitality industry is currently reeling under the effects of fierce competition (Khalifa and Abou-Shouk, 2014; Abd-Elaziz et al., 2015; Khalefa, 2015; Badran and Khalifa, 2016; Dhar, 2016; Khalifa and Hewedi, 2016; Qoura and Khalifa, 2016; Abou-Shouk and Khalifa, 2017; Khalifa and Fawzy, 2017; Mohamud et al., 2017). The United Arab Emirates (UAE) tourism industry is not different; the UAE's government is seeking different renewable resource to boost its economy. The tourism industry is a major renewable resources in UAE, especially, Dubai. Hoteliers in Dubai searching varied techniques to increase their competitive advantages in order to increase their market share (Altin et al., 2018; Eid and Elbanna, 2018). As a result, tourist hotels have started to explore creative ways to attract and retain their customers by encouraging their employees to come up with creative and novel ideas related to hospitality products, services and processes (Wang and Hsiao, 2014; Wang et al., 2014; Dhar, 2016; Altin et al., 2018) in order to improve service quality and maintain sustainable growth (Robinson and Beesley, 2010; Hon, 2011). In this regard, developing innovative ideas can help for hotel managers create unique and attractive services that meet customer's requirements and increase their market share, growth and profitability (Lin et al., 2010; Weng et al., 2016).
"Innovation and creativity in the workplace have become increasingly important determinants of organizational performance, success and longer-term survival. As organizations seek to harness the ideas and suggestions of their employees, it is axiomatic that the process of idea generation and implementation has become a source of distinct competitive advantage (Anderson et al., 2014; Liu et al., 2016; Cai et al., 2018; Khaola and Coldwell, 2019)".

"Supervisor Support (SS) plays an import role in enhancing Employee Innovative Behavior (EIB). This behavior has great importance for organizational productivity and survival which finally lead to the sustainability of organizational development. The EIB means generating new idea and effective multitasking processes which should be performed by the supervisors/managers. Naturally, organizations increasingly seek different ways to foster employee creativity. "The research to grasp effective leadership has become one of the most important goals and common aspiration for researchers, individuals and organizations (Wang et al., 2015; Chen et al., 2016). With significant and rapid technological, cultural, demographic and economic changes in our knowledge-based economy, employee creativity has become an increasingly crucial challenge for organizations to develop employees, enhance the core competence of the corporation and help organizations not only survive but also maintain sustainable competitive advantage in the global market (Wang et al., 2015)".

Corresponding Author: Nasser A.O.M. Alareefi, Faculty of Business and Accountancy, Lincoln University College (LUC), Selangor, Malaysia 
"Supervisor leader is one of the most influential predictors of EIB (Birdi et al., 2016; Chen et al., 2016). Many organizations apply different types of stimulating actors to promote innovative behavior among employees. To articulate individual and organizational level innovation, employees depend on each other for knowledge sharing and consider themselves an integral part of the organization (Wisse et al., 2015; Kang et al., 2016). Knowledge sharing is considered a key promoter in shaping an innovative organization but the factors that promote or discourage knowledge sharing are poorly understood and studied. Sharing the knowledge between the supervisor and his/her employees shows a strong LMX and trust (Wisse et al., 2015). This study attempts to achieve the following research objectives: to examine the effect of in ST on employee innovative behavior. To examine the effect of PSS on employee innovative behavior. To examine the effect of LMX on employee innovative behavior.

\section{Theoretical framework and hypothesis formulation} Supervisor trust and employee innovative behavior: DeConinck and Johnson (2009) and DeConinck (2010) discussed the concept of trust in social relationships "Since, social exchange requires trusting others to reciprocate, the initial problem is to prove oneself trustworthy". Trust is an important element of social exchanges because when one person provides a benefit to another person, the person must trust that the other party will reciprocate. Mutual reciprocation over time will create trust and a commitment to continue the relationship (Homans, 1958; Konovsky and Pugh, 1994). A distinction needs to be made between supervisory trust (direct leaders) and organizational trust (organizational leaders). Unfortunately, little empirical research exists distinguishing between the two forms of trust. According to Bass and Stogdill (1990), direct leaders perform supervisory activities whereas organizational leaders are involved with making strategic decisions".

Tan and Tan (2000) define trust in the supervisor as "involving the day-to-day interaction between the supervisor and employee whereas organizational trust involves relations with a variety of constituent groups in the organization. Outcomes such as job satisfaction, organizational citizenship behavior and performance are associated with the direct supervisor while organizational commitment is related more strongly with trust in the organization". The results of the recent meta-analyses conducted by Dirks and Ferrin, (2002) and Colquitt et al. (2007) revealed that "trust-in-supervisor reflects employee's evaluations of their supervisor's trustworthiness based on interactions with the supervisor (Wong et al., 2002; Luo, 2005). Past research found that leadership is pivotal to building trust in organizational settings ( $\mathrm{Li}$ and Shi, 2008) and trust plays an important role in explaining leadership effectiveness (Yang et al., 2009; Yang and Mossholder, 2010; Carter et al., 2013). Prior research has also suggested that trust-in-supervisor is a key mediator of the relationship between interactional justice and work behaviours (Pillai et al., 1999; Aryee et al., 2002; Wong et al., 2002, 2006). In addition, reciprocity values are strongly endorsed and relationships are highly valued in the Chinese context (Chen et al., 2009), provides a mechanism embodying the crucial requirements of trust among Chinese people (Luo, 2005). Wu et al. (2012) therefore, contend that trust-in-supervisor may well capture the social exchanges between supervisors and subordinates (Huang et al., 2010). Wu et al. (2012) reported that employee's perceptions of the interactional justice of their paternalistic supervisors will affect trust-in-supervisor which is associated with employee's work behaviours".

"Besides as Tastan and Davoudi (2015) mentioned, high levels of trust in leader influences subordinate performance and influences the quality of the organizational outputs. Walumbwa et al. (2011) implied that subordinates with high levels of trust in leader are more motivated and willing to perform activities concerning the well-being of the organization. Chenhall (2005) addressed that employee's trust in leader facilitates reaching the individual and organizational goals, participation in problem solving and developing innovative strategies (Chenhall and Langfield-Smith, 2003). An empirical study among public sector employees has revealed that trust in leader influenced employee's innovative behavior significantly (Tastan and Davoudi, 2015). In this context, it is recognized that the literatures on trust in leader and innovative work behavior provides few researches explaining the influence of employee's trust in leader on their innovative work behavior". Consequently, the following hypothesis is proposed:

- $\mathrm{H}_{1}$ : supervisor trust has a positive effect on EIB

Leader-Member Exchange (LMX) and employee innovative behavior: The role of leaders and their relationship with subordinates have long been considered critical for employee performance (Howell and Hall-Merenda, 1999; Janssen and Van Yperen, 2004; Wang et al., 2005; Erdogan and Enders, 2007; Restubog et al., 2010; Walumbwa et al., 2011, 2017; Zhang et al., 2012). LMX theory contends that leaders 
develop a different relationship with each of their subordinates through a series of work-related exchanges (Graen and Scandura, 1987; Graen and Uhl-Bien, 1995). High-quality LMX relationships tend to be characterized by mutual respect, liking and trust (Dansereau et al., 1975). The quality of LMX reflects a specific form of social exchange within the organization (Cropanzano et al., 2002; Masterson et al., 2000; Restubog et al., 2010; Walumbwa et al., 2017). Social exchange theory posits that individuals give benefits to others in expectation of receiving benefits of equivalent value from them in return (Howell and Hall-Merenda, 1999; Martin et al., 2016). In addition, the norm of reciprocity suggests that people come to feel themselves under obligation and in turn want to help persons and organizations that have helped them (Sekiguchi et al., 2008; Audenaert et al., 2016; Martin et al., 2016).

Once a certain quality LMX relationship has been formed, the relationship between the leader and the members of each group has distinct characteristics. Individuals with a high-quality LMX are provided with more authority to make decisions (Schriesheim et al., 1998; Yukl and Fu, 1999) are given special information to help them complete tasks (Schriesheim et al., 1998) are consulted prior to decisions (Yukl and Fu, 1999) and are given special mentoring opportunities (Graen and Scandura, 1987). Therefore, high-quality LMX will lead to greater motivation to perform their tasks well and engage in OCBs Drawing on what discussed.

"LMX (LMX) theory describes how leaders develop different exchange relationships with their followers (Dansereau et al., 1975; Graen and Scandura, 1987). Exchange relationships (or more commonly, exchanges) are defined as mutually influencing transactions leading to the development of social relationships over time (Hollander, 1978). For example, during such transactions, leaders may receive approval in the form of status, esteem, loyalty and the potential for more influence. In return, followers may receive intrinsic and extrinsic rewards such as authority, freedom, promotion, bonuses, favorable job assignments and the potential for more of the same (Basu and Green, 1997; Basu et al., 2002).

"On the other hand, the previous literature confirms that quality of LMX is positively related to follower's role clarity, job satisfaction, organizational commitment, social interactions, job performance and citizenship behaviors and negatively related to role ambiguity, role conflict, intentions to turnover and innovative behavior (Bauer and Green, 1996; Wayne et al., 1997; Schriesheim et al., 1998; Mayfield and Mayfield, 2009; Dhar, 2016). It is suggested that basically Social Exchange Theory (SET) explains the interaction of leaders and employees and the reasons for differences in the influences of LMX quality on individual outcomes (Xerri, 2013; Tastan and Davoudi, 2015). Most of the research has also shown that higher LMX increases employee creativity and innovative behaviors. Amabile et al. (2004) studies on the componential theory of creativity and showed that leaders can impact the level and frequency of follower's creative behaviors. Shalley and Gilson (2004) study investigated the relationship between a supervisor's LMX quality and employee creativity (Volmer et al., 2012). A number of studies also provided substantial support for the positive relationships between high LMX quality and creativity (Volmer et al., 2012; Xerri, 2013; Tastan and Davoudi, 2015). Consequently, the following hypothesis is proposed:

\section{- $\mathrm{H}_{2}$ : LMX influences positively on EIB}

PSS and employee innovative behaviour: "Supervisors serve critical roles in influencing service employees and important service outcomes (Schneider et al., 1992; Liaw et al., 2010; Dong et al., 2015; Cooper et al., 2016). Research on customer service management has suggested that supervisor's leadership style can shape employee's attitudes, behaviors and performance (Dietz et al., 2004; Al-husseini and Elbeltagi, 2018; Hoch et al., 2018). For example, Schneider and colleagues (Schneider et al., 2002, 2005; Liao and Chuang, 2007; Schneider and George, 2011) found that service oriented leadership impacted employee service quality, customer satisfaction and unit sales by cultivating a proservice climate. Liao and Chuang (2007) found that transformational leadership was positively related to the desirable service outcomes at both the individual and team levels".

"Supervisors play a key role in supporting or inhibiting employee creativity (Sosik et al., 1998; Shalley et al., 2004; Hon, 2010; Volmer et al., 2012; Wang et al., 2014; Cai et al., 2018). On the basis of the employee creativity literature, here the researcher considers three alternative ways in which supervisors can support creativity: through providing developmental feedback, through displaying interactional justice and through being trustworthy. Each of these ways supervisors can support creativity pertain directly to the creative idea generation of subordinates per se, rather than to the more general ways in which supervisors can provide a supportive context. More specifically, developmental feedback instills a learning/improvement orientation that is vital for creativity, interactional justice ensures that subordinates will have the knowledge and information they need to be creative and will be treated with respect even if their ideas don't pan out and trust 
reassures them that their hard work and risk taking are well worth the effort because supervisors have the competence and professionalism to follow through on creative ideas (Amabile et al., 2004; Shalley and Gilson, 2004; Hon, 2011; Dong et al., 2015; Chen and Hou, 2016; Cai et al., 2018). Hence, it is hypothesized as follows:

\section{- $\mathrm{H}_{3}$ : PSS influences positively on EIB}

Employees Innovative Behavior (EIB): Employee innovative behavior, defined as "the generation, promotion and implementation of novel and useful ideas" (Chen et al., 2016). Innovation processes include several stages. First and perhaps foremost, creativity, formally defined as the generation of novel and useful ideas (Amabile et al., 1996; Paulus and Yang, 2000) is the obvious point of departure for innovation to take place. Another important phase, however is selecting and implementing the chosen alternatives (Scott and Bruce, 1994; Amabile et al., 2004; Hammond et al., 2011). In reality, the innovation process is complex and idea generation and implementation do not necessarily proceed in a linear fashion but can take place interchangeably (Anderson et al., 2004). However, creative-idea generation is widely accepted as the necessary antecedent of innovation implementation at the individual level (Amabile et al., 1996). For research purposes, such a distinction enables a deeper and more nuanced insight into the innovation process which could help the managers provide knowledge of how to stimulate idea implementation from idea generation as it is this final step that provides a tangible value for the firm. If organizations fail to implement highly creative ideas, this would mean sunk costs because they fall short of contributing to the business case (Levitt, 2002).

\section{MATERIALS AND METHODS}

Overview of the proposed research model: For this study, the hypothesized variables and their relationships in the model have been derived from the available literature of the models and theories that have been prescribed in the literature mentioned in Fig. 1. While examining the proposed model, it can be seen that LMX and AOC along with EL predicts employees performance. These relationships are derived from (Li et al., 2017) for PSS, (Scott and Bruce, 1994) for EIB, (McAllister, 1995) for ST and (Scandura et al., 1986; Wayne et al., 1997) for LMX. The proposed extended model examines the relationship between PSS, ST and LMX as antecedent variables that explain EIB as an output variable

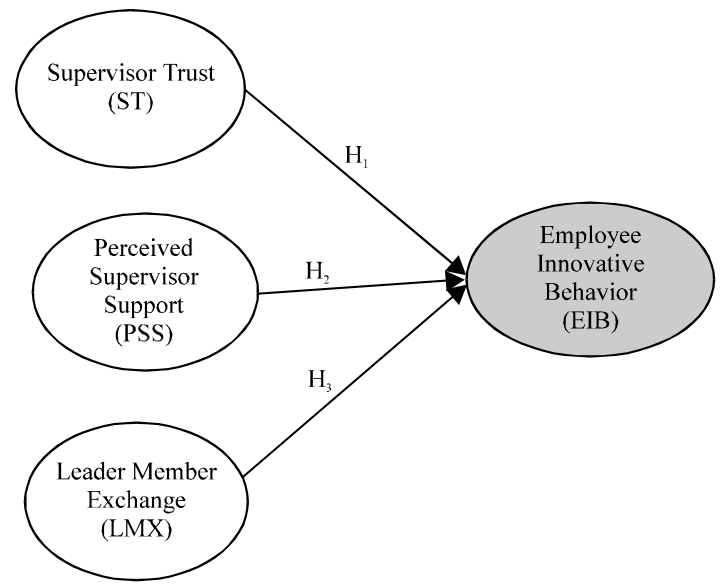

Fig. 1: Proposed research model; PSS: Percieved Supervisor Support, LMX: Leader-Member Exchange, EIB: Employee Innovative Behavior, ST: Supervisor Trust

among employees in Dubai's five star hotels within the United Arab Emirates. The proposed model has three hypothesis to test.

Development of instrument: A 21-item questionnaire was developed for this study. Because the respondents were Arab-speaking, it was imperative that it be accurately translated from English to Arabic. Back translation was used in this study, a procedure commonly used in cross-cultural surveys to test the accuracy of the translation (Brislin, 1970).

This study applied multi-item Likert scales which have been widely used in the questionnaire-based perception studies (Lee et al., 2009). Unlike actual usage which is measured using a 7-point ranking scale, other variables are subjectively measured using the 7-point Likert scale with 7 being 'Strongly Agree' and 1 being 'Strongly disagree'. For this study, a pre-testing was conducted with 30 hotel employees to resolve any ambiguity associated with wording or measurement. Then the items were pilot-tested to examine their internal consistency. Out of 675 surveys administered to UAE employees in the Dubai's five star hotels, 504 were returned with complete and valid data. In the final questionnaire, all items had acceptable reliability as the individual Cronbach's alpha coefficients of the constructs which ranged from $0.867-0.948$ were all greater than the recommended value of 0.7 (Nunnally and Bernstein, 1994).

Data collection: The participants in the current study are the five-star hotel's managers and their front line employees in UAE hospitality sector. The researcher targeted the front line employee because those employees 
have a great opportunity to contact directly with the customers. The direct contact allows those employees to deal with varied customer needs and wants and different customer problems. This communication generates employee innovative behavior (Dhar, 2016). Questionnaires were administered to the five-star hotel's managers and employees. The researcher used the employee ID lists provided by HR departments. The participants received a questionnaire with introduction cover letter conducted and coded by the researchers. To secure confidentiality, the participants were informed to place completed questionnaire into a sealed envelope and return them directly to the researcher's address. Data collection was conducted using a self-administered paper questionnaire which was delivered 'in-person' from August 2017 until March 2018 to five star hotel employee and their immediate supervisors. The employees were approached while in main facilities at hotel institutions. A total of 675 questionnaires were distributed with 522 sets returned of which 504 responses were useful for the analysis. The final sample size was considered as adequate (Krejcie and Morgan, 1970; Tabachnick and Fidell, 2012). The $74.7 \%$ response rate is considered very good (Cable and DeRue, 2002) and above average (Baruch and Holtom, 2008) by comparison with other studies found in the relevant literature. A total of 18 questionnaires were deleted of which 15 cases were removed due to missing data for more than $15 \%$ of the questions and 3 cases involving straight lining.

\section{RESULTS AND DISCUSSION}

Descriptive analysis: The researcher investigated 27 out of 56 five-star hotels in Dubai, UAE which accepted to participate in the study. This study targeted all front line employees. The researcher distributed 675 questioners, the valid questionnaires were received by the researcher are 504 questionnaires by responding rate is $75 \%$. The responding sample $(\mathrm{n}=504)$ consisted of $61.9 \%$ male and $38.1 \%$ female employees. The age group of twenties has the highest population approximately $40 \%$, the second in terms is the age of thirties followed by employee of forties (27 and $24.2 \%$, respectively). It was noted that the young and old employees were far less widespread in the Dubai hospitality industry (Table 1). Also, evident is the fact that employees with Bachelor degree had dominated the front line jobs in this industry, at some $60 \%$ while diploma degree was more common, at somewhere to the vicinity $24.2 \%$ meanwhile postgraduate had a mere $15.2 \%$. Surprisingly, more that $50.6 \%$ employees had work tenure from 6-10 years. In addition, $<0.04 \%$ employees had work tenure over 20 years (Table 1 ).
Table 1: Summary of demographic profile of respondents

\begin{tabular}{lrr}
\hline Variables & Frequency & Valid (\%) \\
\hline Gender & & \\
Male & 312 & 61.90 \\
Female & 192 & 38.10 \\
Age & & \\
$18-20$ & 40 & 0.08 \\
$21-30$ & 171 & 33.90 \\
$31-40$ & 136 & 27.00 \\
$41-50$ & 121 & 24.20 \\
Over 50 & 76 & 15.05 \\
Education & & \\
Diploma & 122 & 24.20 \\
Graduation & 304 & 60.30 \\
Post graduation & 78 & 15.50 \\
Tenure & & \\
$1-5$ & 196 & 38.90 \\
6-10 & 265 & 50.60 \\
$11-15$ & 137 & 27.20 \\
$16-20$ & 44 & 0.10 \\
21-25 & 13 & 0.03 \\
0ver 25 & 5 & 0.01 \\
\hline
\end{tabular}

Measurement model assessment: This study employed Structural Equation Modeling-Variance Based (SEM-VB) through Partial Least Squares (PLS) method to analyze the research model using the software of SmartPLS 3.0 (Ringle et al., 2015). After the descriptive analysis, this study follows the two-stage analytical technique recommended by Anderson and Gerbing (1988), Hair et al. (2017) starts with the measurement model assessment (validity and reliability), followed by the structural model assessment (testing the hypothesized relationships). Schumacker and Lomax (2004) and Hair et al. (2010) indicate that the two steps assessment procedure which includes measurement model and structural model has an advantage over the one step assessment procedure. According to Hair et al. (2017) measurement model specifies how each construct is measured while structural model specifies how the variables are related to each other in the structural model. The main reasons for choosing PLS as a statistical method for this study that for both measurement and structural model PLS offer simultaneous analysis which leads to more accurate estimates (Barclay et al., 1995).

The assessment of measurement model was done through construct reliability as well as validity (including convergent and discriminant validity). For construct reliability, this study tested the individual Cronbach's alpha coefficients to measure the reliability of each of the core variables in the measurement model. The results indicate that all the individual Cronbach's alpha coefficients ranging from $0.867-0.948$ were higher than the suggested value of 0.7 (Kannana and Tan, 2005; Nunnally and Bernstein, 1994). Additionally, for testing construct reliability all the Composite Reliability $(\mathrm{CR})$ values ranging from 0.904-0.957 were higher than 0.7 (Werts et al., 1974; Kline, 2010; Gefen et al., 2000) which adequately indicates 
Pak.J. Soc. Sci., 16 (1): 14-29, 2019

Table 2: Mean, standard deviation, loading, Cronbach's alpha, CR and AVE

\begin{tabular}{|c|c|c|c|c|c|c|}
\hline Constructs/Items & Loading $(>0.5)$ & $\mathrm{M}$ & $\mathrm{SD}$ & $\alpha(>0.7)$ & $\mathrm{CR}(>0.7)$ & $\operatorname{AVE}(>0.5)$ \\
\hline \multicolumn{7}{|c|}{ Perceived Supervisor Support (PSS) } \\
\hline $\mathrm{SS} 2$ & 0.857 & 4.071 & 0.788 & 0.901 & 0.930 & 0.769 \\
\hline SS3 & 0.895 & & & & & \\
\hline SS4 & 0.891 & & & & & \\
\hline SS1 & 0.865 & & & & & \\
\hline \multicolumn{7}{|c|}{ Leader-Member Exchange (LMX) } \\
\hline LMX1 & 0.888 & 4.144 & 0.777 & 0.948 & 0.957 & 0.762 \\
\hline LMX2 & 0.867 & & & & & \\
\hline LMX 3 & 0.867 & & & & & \\
\hline LMX 4 & 0.867 & & & & & \\
\hline LMX 5 & 0.859 & & & & & \\
\hline LMX6 & 0.856 & & & & & \\
\hline LMX7 7 & 0.904 & & & & & \\
\hline \multicolumn{7}{|c|}{ Supervisor Trust (ST) } \\
\hline ST1 & 0.819 & 4.442 & 0.978 & 0.867 & 0.904 & 0.652 \\
\hline ST2 & 0.813 & & & & & \\
\hline ST3 & 0.788 & & & & & \\
\hline ST4 & 0.798 & & & & & \\
\hline ST5 & 0.820 & & & & & \\
\hline \multicolumn{7}{|c|}{ Employee Innovative Behavior (EIB) } \\
\hline EIB1 & 0.846 & 4.762 & 0.888 & 0.889 & 0.919 & 0.693 \\
\hline EIB2 & 0.831 & & & & & \\
\hline EIB3 & 0.827 & & & & & \\
\hline EIB4 & 0.820 & & & & & \\
\hline EIB5 & 0.839 & & & & & \\
\hline
\end{tabular}

$\mathrm{M}=$ Mean; $\mathrm{SD}=$ Standard Deviation, $\alpha=$ Cronbach's alpha; $\mathrm{CR}=$ Composite Reliability, $\mathrm{AVE}=$ Average Variance Extracted; The measurement used is seven-point scale ranging from 1 (strongly disagree) to 7 (strongly agree). All the factor loadings of the individual items are statistically significant ( $p<0.01$ )

that construct reliability is fulfilled as shown in Table 2. Therefore, the achieved Cronbach's alpha and CR for all constructs were considered to be sufficiently error-free.

Factor loading was used to test indicator reliability. High loadings on a construct indicate that the associated indicators seem to have much in common which is captured by the construct (Hair et al., 2017). Factor loadings $>0.50$ were considered to be very significant (Hair et al., 2010). The loadings for all items exceeded the recommended value of 0.5 as shown in Table 2. The loading for all items in the model has therefore, fulfilled all the requirements.

For testing convergent validity (the extent to which a measure correlates positively with alternative measures of the same construct), this study used the Average Variance Extracted (AVE) and it indicated that all AVE values were higher than the suggested value of 0.50 (Hair et al., 2010) ranging from 0.652-0.769. The convergent validity for all constructs has been successfully fulfilled and adequate convergent validity exhibited as Table 2 shows.

The discriminant validity (the degree to which items differentiate among constructs or measure distinct concepts) of the measurement model was checked using three criteria, namely cross-loadings, Fornell-Larcker and the Heterotrait-Monotrait ratio (HTMT). According to Hair et al. (2017), the cross-loadings are typically the first approach to assess discriminant validity of the indicators.

\begin{tabular}{lllll}
\multicolumn{5}{l}{ Table 3: Results of discriminant validity by the cross loading } \\
\hline Items & EIB & LMX & PSS & ST \\
\hline EIB1 & $\mathbf{0 . 8 4 6}$ & 0.238 & 0.187 & 0.496 \\
EIB2 & $\mathbf{0 . 8 3 1}$ & 0.213 & 0.195 & 0.487 \\
EIB3 & $\mathbf{0 . 8 2 7}$ & 0.202 & 0.194 & 0.460 \\
EIB4 & $\mathbf{0 . 8 2 0}$ & 0.203 & 0.193 & 0.466 \\
EIB5 & $\mathbf{0 . 8 3 9}$ & 0.160 & 0.191 & 0.458 \\
LMX1 & 0.242 & $\mathbf{0 . 8 8 8}$ & 0.361 & 0.524 \\
LMX2 & 0.215 & $\mathbf{0 . 8 6 7}$ & 0.322 & 0.481 \\
LMX3 & 0.234 & $\mathbf{0 . 8 6 7}$ & 0.333 & 0.449 \\
LMX4 & 0.201 & $\mathbf{0 . 8 6 7}$ & 0.290 & 0.458 \\
LMX5 & 0.187 & $\mathbf{0 . 8 5 9}$ & 0.281 & 0.490 \\
LMX6 & 0.200 & $\mathbf{0 . 8 5 6}$ & 0.280 & 0.484 \\
LMX7 & 0.206 & $\mathbf{0 . 9 0 4}$ & 0.332 & 0.509 \\
ST1 & 0.457 & 0.475 & 0.180 & $\mathbf{0 . 8 1 9}$ \\
ST2 & 0.471 & 0.432 & 0.218 & $\mathbf{0 . 8 1 3}$ \\
ST3 & 0.446 & 0.472 & 0.186 & $\mathbf{0 . 7 8 8}$ \\
ST4 & 0.420 & 0.409 & 0.168 & $\mathbf{0 . 7 9 8}$ \\
ST5 & 0.498 & 0.454 & 0.225 & $\mathbf{0 . 8 2 0}$ \\
ss2 & 0.178 & 0.352 & $\mathbf{0 . 8 5 7}$ & 0.240 \\
ss3 & 0.225 & 0.295 & $\mathbf{0 . 8 9 5}$ & 0.187 \\
ss4 & 0.211 & 0.303 & $\mathbf{0 . 8 9 1}$ & 0.213 \\
ss1 & 0.190 & 0.331 & $\mathbf{0 . 8 6 5}$ & 0.221 \\
\hline
\end{tabular}

PSS: Percieved Supervisor Support, LMX: Leader-Member Exchange, EIB: Employee Innovative Behavior, ST: Supervisor Trust

As shown in Table 3 the cross loading criterion fulfills the requirements because the indicators outer loadings on a construct were higher than all its cross-loadings with other constructs (bold values).

The results of discriminant validity by using the Fornell-Larcker criterion is shown in Table 4 where the square root of the AVEs on the diagonals, as represented by the bolded values are higher than the correlations between constructs (corresponding row and column 
values). This indicates that the constructs are strongly related to their respective indicators compared to other constructs of the model (Fornell and Larcker, 1981; Chin, 1998a, b), thus, suggesting a good discriminant validity (Hair et al., 2017). In addition, the correlation between exogenous constructs is $<0.85$ (Awang, 2014). Hence, the discriminant validity of all constructs is fulfilled.

There has been some criticism of the Fornell-Larcker criterion, Henseler et al. (2015) mentioned that it does not accurately reveal the lack of discriminant validity in common research situations. They have proposed an alternative technique which is the Heterotrait-Monotrait

\begin{tabular}{lllll}
\multicolumn{5}{l}{ Table 4: Results of discriminant validity by Fornell-Larcker criterion } \\
\hline Factors & 1 & 2 & 3 & 4 \\
\hline EIB & $\mathbf{0 . 8 3 3}$ & & & \\
LMX & 0.244 & $\mathbf{0 . 8 7 3}$ & & \\
PSS & 0.231 & 0.362 & $\mathbf{0 . 8 7 7}$ & \\
ST & 0.569 & 0.556 & 0.243 & $\mathbf{0 . 8 0 8}$ \\
\hline
\end{tabular}

Diagonals represent the square root of the average variance extracted while the other entries represent the correlations. PSS: Percieved Supervisor Support, LMX: Leader-Member Exchange, EIB: Employee Innovative Behavior, ST: Supervisor Trust

Table 5: Results of discriminant validity by HTMT

\begin{tabular}{lllll}
\hline Factors & 1 & 2 & 3 & 4 \\
\hline EIB & & & & \\
LMX & 0.264 & & & \\
PSS & 0.256 & 0.392 & & - \\
ST & 0.646 & 0.612 & 0.276 & -
\end{tabular}

PSS: Percieved Supervisor Support, LMX: Leader-Member Exchange, EIB: Employee Innovative Behavior, ST: Supervisor Trust ratio (HTMT) of correlations based on the multitrait-multimethod matrix. This study assesses discriminant validity through HTMT. While the discriminant validity has a problem when the HTMT value is greater than $\mathrm{HTMT}_{0.90}$ value of 0.90 (Gold et al., 2001) or the $\mathrm{HTMT}_{0.85}$ value of 0.85 (Kline, 2010), all values as Table 5 shows were lower than the recommended value of 0.85 indicating that discriminant validity has been ascertained.

Structural model assessment: Hair et al. (2017) suggested assessing the structural model by looking at the beta $(\beta), \mathrm{R}^{2}$ and the corresponding t-values via. a bootstrapping procedure with a resample of 5.000 . Moreover, they recommend reporting the effect sizes $\left(\mathrm{F}^{2}\right)$ as well as the predictive relevance $\left(\mathrm{Q}^{2}\right)$. As Sullivan and Feinn (2012) argue that the p-value determine whether the effect exists but it does not reveal the size of the effect.

Hypothesis tests: The structural model assessment as shown in Fig. 2 and Table 6 provides the indication of the hypothesis tests with 3 out of the 3 hypothesis are supported. PSS, LMX and ST significantly predict employee innovative behavior. Hence, $\mathrm{H}_{1}-\mathrm{H}_{3}$ are accepted with $(\beta=0.619, \tau=14.812, p<0.001),(\beta=0.134, \tau=3.187$, $\mathrm{p}<0.01)$ and $(\beta=-0.148, \tau=3.196, \mathrm{p}<0.01)$, respectively.

Note that the standardized path coefficient indicates the strengths of the relationship between exogenous and endogenous constructs, so, the direct effects of ST

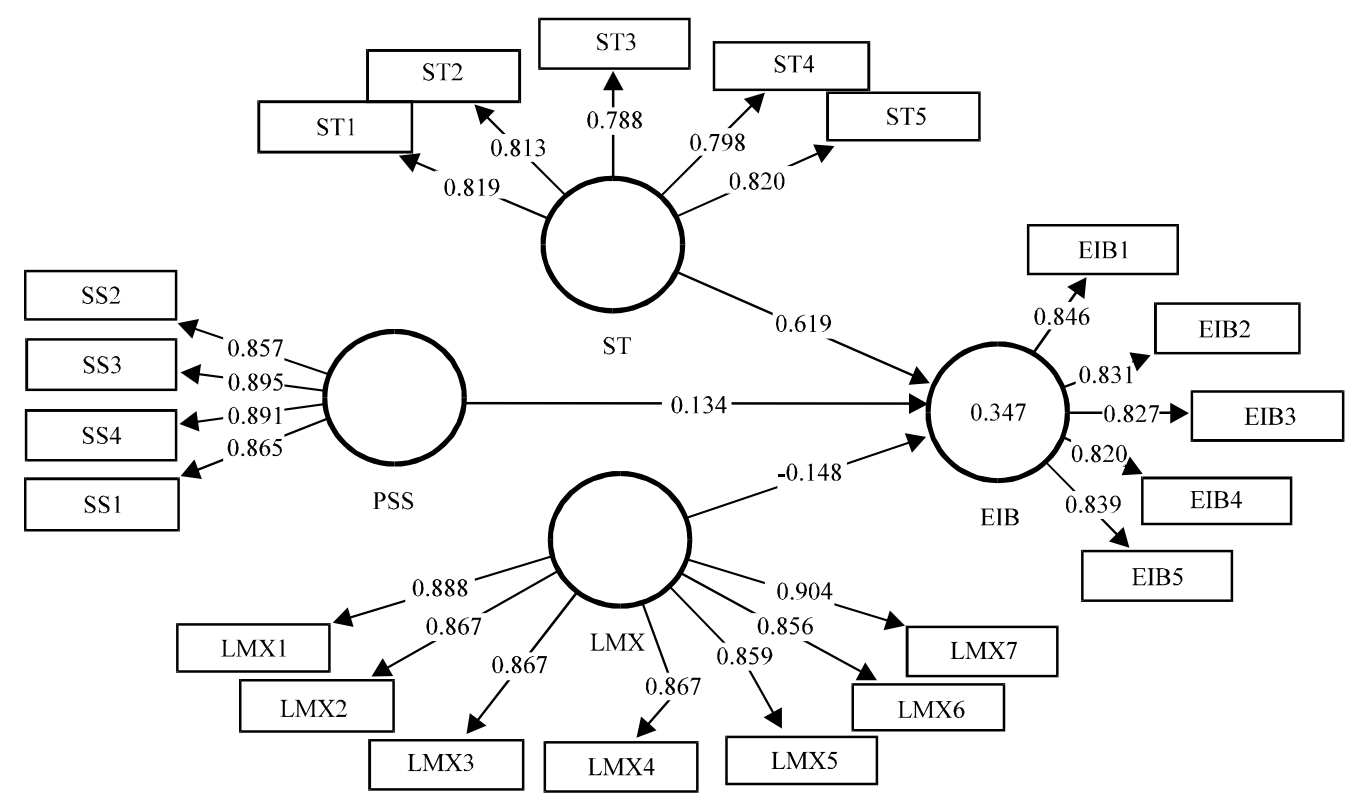

Fig. 2: PLS algorithm results; PSS: Percieved Supervisor Support, LMX: Leader-Member Exchange, EIB: Employee Innovative Behavior, ST: Supervisor Trust 
Pak.J. Soc. Sci., 16 (1): 14-29, 2019

Table 6: Structural path analysis results

\begin{tabular}{|c|c|c|c|c|c|c|c|c|c|c|}
\hline Hypothesis & Relationship & SD beta & SD error & $t$-values & p-values & Decision & $\mathrm{R}^{2}$ & $\mathrm{~F}^{2}$ & $\mathrm{Q}^{2}$ & VIF \\
\hline $\mathrm{H}_{1}$ & ST->EIB & 0.619 & 0.042 & 14.812 & 0.000 & Supported & 0.347 & 0.404 & 0.235 & 1.222 \\
\hline $\mathrm{H}_{2}$ & PSS->EIB & 0.134 & 0.042 & 3.187 & 0.002 & Supported & & 0.024 & & 2.654 \\
\hline$\underline{\mathrm{H}_{3}}$ & LMX $>$ EIB & -0.148 & 0.046 & 3.196 & 0.001 & Supported & & 0.021 & & 1.343 \\
\hline
\end{tabular}

PSS: Percieved Supervisor Support, LMX: Leader-Member Exchange, EIB: Employee Innovative Behavior, ST: Supervisor Trust

on EIB are much stronger than the influence of other variables. PSS, ST and LMX explaining $34.7 \%$ of the variance in EIB. The $\mathrm{R}^{2}$ values achieved an acceptable level of explanatory power as recommended by Cohen (1988) and Chin (1998a, b).

This study also assessed effect sizes $\left(\mathrm{F}^{2}\right)$. Effect size $\mathrm{F}^{2}$ determines whether an exogenous latent construct has a substantial, moderate or weak impact on an endogenous latent construct (Gefen and Rigdon, 2011). Hair et al., (2017) recommend to test the change in the $R^{2}$ value. Cohen (1988) suggested a guideline measure the magnitude of the $\mathrm{F}^{2}$ which is 0.35 (large effects), 0.15 (medium effects) and 0.02 (small effects). The result of $\mathrm{F}^{2}$ as Table 6 shows that two relationship with medium effect sizes and one relationships with small effect sizes.

Further by using the blindfolding procedure this study examined the power of research proposed model regarding the predictive relevance. As recommended by Hair et al. (2017) the blindfolding procedure should use only on the endogenous constructs with a reflective measurement. If the value of $Q^{2}$ is $>0$ then the predictive relevance of the proposed model exists for a certain endogenous construct (Fornell and Cha, 1994; Hair et al., 2017). As Table 6 shows that all the values of $Q^{2}>0$ indicate that there is an adequate predictive relevance for the proposed model. For the $\mathrm{Q}^{2}$ values, Hair et al. (2017) suggested values of 0.35 (large), 0.15 (medium) and 0.02 (small) as a relative measure of predictive relevance and the result of this study shows that the exogenous have medium predictive relevance.

An issue of the multicollinearity could exist in any study which is not desirable, it means that the variance exogenous constructs explain in the endogenous construct are overlapping with each other and thus not each explaining unique variance in the endogenous variable (O'Brien, 2007). To measure and assess the degree of multicollinearity, Variance Inflation Factor (VIF) widely used (O'Brien, 2007). There is cause for concern when the largest VIF is $>10$ (Bowerman and $\mathrm{O}^{\prime}$ Connell, 1990; Myers, 1990). And according to Hair et al., (2017) a multicollinearity issue exists when the largest VIF is $>5$. Table 6 shows multicollinearity diagnostic through VIF which indicates that there is no evidence of significant multicollinearity among the study exogenous constructs because all VIF values are $<5$ ranging from 1.222-2.654. It means that the variance of exogenous constructs explains in the endogenous construct are not overlapping with each other.
Table 7: IPMA for employ ee innovation

\begin{tabular}{lcc}
\hline $\begin{array}{l}\text { Latent } \\
\text { constructs }\end{array}$ & $\begin{array}{c}\text { Total effect of the } \\
\text { construct EIB } \\
\text { (Importance) }\end{array}$ & $\begin{array}{c}\text { Index values } \\
\text { (Peformance) }\end{array}$ \\
Supervisor Support (PSS) & 0.119 & 57.398 \\
Supervisor Trust (ST) & 0.689 & 51.167 \\
Leader-Member Exchange (LMX) & -0.150 & 52.405 \\
\hline
\end{tabular}

Importance-Performance Map Analysis (IPMA): This study ran an Importance-Performance Matrix Analysis (IPMA) as a post-hoc procedure in PLS using organizational performance as the outcome construct. The IPMA estimates the total effects represented by the importance of predecessor constructs in shaping the target construct (organizational performance) while their average latent variable scores represent their performance, the computation of the index values (performance scores) was accomplished by rescaling the latent constructs scores to a range of 100 (highest performance) down to 0 (lowest performance) (Hair et al., 2017). According to Ringle and Sarstedt (2016) IPMA enriches the PLS analysis results. Instead of only analyzing the path coefficients (i.e., the importance dimension), it also takes into consideration the average value of the latent constructs and their indicators (i.e., performance dimension). Table 7 shows the findings of importance (total effects) and performance (index values) used for the IPMA.

As shown in Fig. 3 this study plotted the total effects scores and index values in a priority map. It can be observed that ST is a very important factor in determining the employee innovative behavior due to its relatively higher importance value compared to other constructs in the proposed model.

Nevertheless, the performance of this Significant factor (ST) lagged behind the LMX and PSS. According to Hair et al. (2017) The goal of IPMA is to identify predecessors that have a relatively high importance for the target construct (i.e., those that have a strong total effect) but also a relatively low performance (i.e., low average latent variable scores), the aspects underlying these constructs represent potential areas of improvement that may receive high attention. In sum, in order to improve the employee innovative behavior, the managerial activities should focus on enhancing the performance of ST.

Based on the proposed model, this study improves the understanding of the role played by PSS, LMX and ST 
Pak.J. Soc. Sci., 16 (1): 14-29, 2019

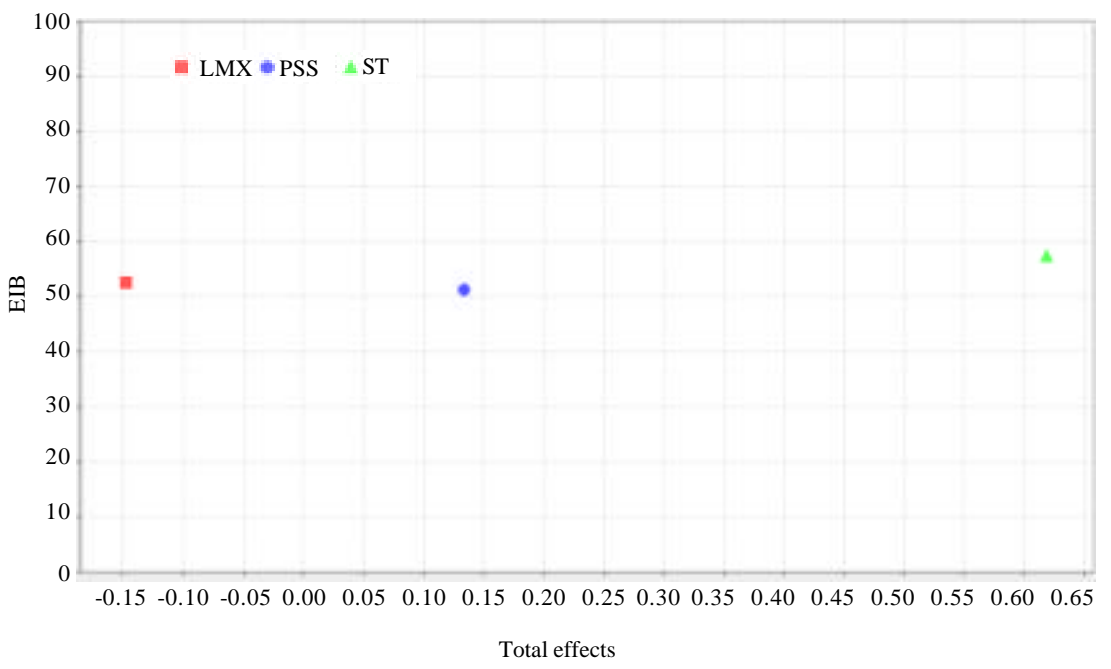

Fig. 3: IPMA (Priority Map) for employee innovative behavior (PSS: Percieved Supervisor Support, LMX: Leader-Member Exchange, EIB: Employee Innovative Behavior, ST: Supervisor Trust

in the employee innovative behavior at Dubai's five star hotels in the United Arab Emirates and highlights relevant implications and suggestions for management and policy makers. The discussions are further detailed in the following.

The study found that PSS positively affect employee innovative behavior among hotel employees within the Dubai five star hotels in the United Arab Emirates, this is supported by previous studies (Jung et al., 2003; Elenkov and Manev, 2005; Montes et al., 2005; Aragon-Correa et al., 2007; Makri and Scandura, 2010; Radzi et al., 2013; Donate and de Pablo, 2015). It is explained by the fact that the more the leadership of the organization is committed to establishing directions that will be aligned with all activities, teams and units that will ultimately be at the best interests of Dubai hotel service needs, besides encouraging cooperation, team work and social responsibility commitment, the more resource efficient the organization become and more likely to achieve optimal quality, besides meeting its benchmarks on time to perform its duties.

Likewise, it was found that ST positively affect employee innovative behavior among employees within the five star hotels in the United Arab Emirates, this is supported by previous studies (Bysted, 2013; Dhar, 2016; Chen et al., 2017). In this knowledge-based economy, it has become more important than ever in understanding individual work-related behavior because it is identified as more stable and less subject to daily fluctuations than job satisfaction (Joo, 2010).

Additionally, LMX was found to negatively affect employee innovative behavior among respondents within the five star hotels in the United Arab Emirates, this is not supported by previous studies (Graen and Uhl-Bien, 1995; Garg and Dhar, 2014; Dhar, 2016; Epitropaki et al., 2016; Martin et al., 2016). Finally, according to the importance-performance map analysis, ST scored highest in terms of importance and PSS scored in terms of performance within the tested model. Therefore, in order for Dubai hotels to enhance its employee innovative behavior, leaders need to improve their ethical contribution in terms of moral person dimension and moral manager.

\section{CONCLUSION}

While the United Arab Emirates government institutions are ahead of regional counterparts in terms of performance, it is striving to enhance its organizations' productivity (Index, 2016), the findings of this study could be considered as one of the initiatives to serve on that direction. The main objective of this study is to determine factors that affect employee innovative behavior within Dubai's five star hotels in the United Arab Emirates. Despite various constraints to the study, the results have been encouraging as it has managed to throw some lights on a new perspective. This study proposed a model which includes PSS and ST in addition to LMX as independent variables and employee innovative behavior as the dependent variable. The results revealed that the three independent variables significantly explain $34.7 \%$ of employee innovative behavior. The implications of this study from the perspective of research and practitioners have been deliberated, limitations have been noted and some directions for future research have been suggested. 


\section{LIMITATIONS}

The first limitation concerns the generalizability of the findings, the targeted sampling of this study includes an employee working in hotel institutions in the Dubai only. Another limitation is that data was gathered by cross-sectional and is not longitudinal in nature. The relationships between variables prescribed in the model of this study are highly case-dependent and thus they vary from organization to another, the model was implemented for an example organization which is Dubai's five star hotels.

\section{IMPLICATIONS}

Implications for research: This research study has made use of the available literature of the concept of PSS, ST and LMX by applying it to the context of an organization in the hospitality sector in the United Arab Emirates to examine its role as a source of competitive advantage and its effect on the employee innovative behavior. This research can be seen as an attempt to contribute to the understanding of the organizational innovative behavior that leads to a firm's enhanced productivity and thus enhanced competitive advantage (Rao, 2016). This concept has significant value for researchers interested in employee innovative behavior. Moreover, the variance explained by the proposed model in the current study for employee innovative behavior among workers within the five star hotels in the United Arab Emirates is 34.7\%. The predictive power of the model in this study has therefore a higher ability to explain and predict employee innovative behavior similar to what obtained from some of the previous studies with different variances explained recorded for employee performance: $35.3 \%$ (Ahmad et al., 2014,2016 ). This research offers empirical support to the theoretical relevance of PSS and ST, along with LMX to predict the innovative behavior of employees.

Implication for practice: The present research is of significant for practitioners as it illustrates the importance of ST, LMX and PSS although, a link of causality between the variables of this study cannot be clearly recognized because of the cross-sectional design, the results indicate that PSS, ST and LMX are vital to facilitate and enhance the employee innovative behavior. The order of this sequence should encourage organizations to put more emphasis on nurturing leader's moral person dimension and moral manager one. Moreover, the implications of the key findings provide significant benefits not only for at hotel institutions but also to the UAE service institutions. Incorporating the findings, a number of practical implications were found such as promoting supervisor support behavior as well as ST and LMX which leads to improving employee innovative behavior and quality of work.

It is expected that key findings, especially the proposed model will help in supporting the UAE government policy initiatives, especially to increase innovativeness as part of the job at all levels of organizations. The evidence shows a link between ST and better PSS and innovation.

\section{SUGGESTIONS}

As described in the introduction section of this research. Moreover, the exclusion of other organizational resources, for instance, financial resources represents another limitation of the model. Although, such resources are necessary for organizations in the successful implementation of their capability-building plans, it was decided that taking into account these organizational resources in the model will result in more unnecessary complications to the model and reduce from the main objectives of this research.

\section{REFERENCES}

Abd-Elaziz, M.E., W.M. Aziz, G.S. Khalifa and M. Abdel-Aleem, 2015. Determinants of Electronic Word of Mouth (EWOM) influence on hotel customers purchasing decision. Intl. J. Heritage Tourism Hospitality, 9: 194-223.

Abou-Shouk, M.A. and G.S. Khalifa, 2017. The influence of website quality dimensions on E-purchasing behaviour and E-loyalty: A comparative study of Egyptian travel agents and hotels. J. Travel Tourism Marketing, 34: 608-623.

Ahmad, J., M.R. Athar and M. Hussain, 2016. Linking personality traits with job performance mediating role of organizational commitment: An empirical evidence. NUML. Intl. J. Bus. Manage., 11: 1-11.

Ahmad, N., N. Iqbal, K. Javed and N. Hamad, 2014. Impact of organizational commitment and employee performance on the employee satisfaction. Intl. J. Learn. Teach. Educ. Res., 1: 84-92.

Al-husseini, S. and I. Elbeltagi, 2018. Evaluating the effect of transformational leadership on knowledge sharing using structural equation modelling: The case of Iraqi higher education. Intl. J. Leadersh. Educ., 21: 506-517.

Altin, M., M.A. Koseoglu, X. Yu and A. Riasi, 2018. Performance measurement and management research in the hospitality and tourism industry. Intl. J. Contemp. Hospitality Manage., 30: 1172-1189. 
Amabile, T.M., E.A. Schatzel, G.B. Moneta and S.J. Kramer, 2004. Leader behaviors and the work environment for creativity: Perceived leader support. Leadership Q., 15: 5-32.

Amabile, T.M., R. Conti, H. Coon, J. Lazenby and M. Herron, 1996. Assessing the work environment for creativity. Acad. Manage. J., 39: 1154-1184.

Anderson, J.C. and D.W. Gerbing, 1988. Structural equation modeling in practice: $\mathrm{A}$ review and recommended two-step approach. Psychol. Bull., 103: 411-423.

Anderson, N., C.K. De Dreu and B.A. Nijstad, 2004. The routinization of innovation research: A constructively critical review of the state-of-thescience. J. Organizational Behav., 25: 147-173.

Anderson, N., K. Potocnik and J. Zhou, 2014. Innovation and creativity in organizations: A state-of-thescience review, prospective commentary and guiding framework. J. Manage., 40: 1297-1333.

Aragon-Correa, J.A., V.J. Garcia-Morales and E. Cordon-Pozo, 2007. Leadership and organizational learning's role on innovation and performance: Lessons from Spain. Ind. Marketing Manage., 36: 349-359.

Aryee, S., P.S. Budhwar and Z.X. Chen, 2002. Trust as a mediator of the relationship between organizational justice and work outcomes: Test of a social exchange model. J. Org. Behav., 23: 267-285.

Audenaert, M., A. Decramer, B. George, B. Verschuer and T. Van Waeyenberg, 2016. When employee performance management affects individual innovation in public organizations: The role of consistency and LMX. Intl. J. Hum. Resour. Manage., 1: 1-20.

Awang, Z., 2014. Structural Equation Modeling Using AMOS. Universiti Teknologi MARA Publication Center, Shah Alam, Malaysia,.

Badran, N. and G. Khalifa, 2016. Diversity management: Is it an important issue in hotel industry in Egypt?. Intl. J. Heritage Tourism Hospitality, 7: 275-286.

Barclay, D., C. Hinggins and R. Thompson, 1995. The Partial Least Square (PLS) approach to causal modeling, personal computer adoption and use as an illustration. Technol. Stud. Spec. Issues Res. Method., 2: 285-324.

Baruch, Y. and B.C. Holtom, 2008. Survey response rate levels and trends in organizational research. Hum. Relat., 61: 1139-1160.

Bass, B.M. and R.M. Stogdill, 1990. Bass and Stogdills HandBook of Leadership: Theory, Research and Managerial Applications. 3rd Edn., Simon and Schuster, New York, USA., ISBN:9780029015001, Pages: 1191.
Basu, R. and S.G. Green, 1997. Leader-member exchange and transformational leadership: An empirical examination of innovative behaviors in leader-member dyads. J. Appl. Soc. Psychol., 27: 477-499.

Basu, V., E. Hartono, A.L. Lederer and V. Sethi, 2002. The impact of organizational commitment, senior management involvement and team involvement on strategic information systems planning. Inform. Manage., 39: 513-524.

Bauer, T.N. and S.G. Green, 1996. Development of leader-member exchange: A longitudinal test. Acad. Manage. J., 39: 1538-1567.

Birdi, K., D. Leach and W. Magadley, 2016. The relationship of individual capabilities and environmental support with different facets of designers innovative behavior. J. Prod. Innovation Manage., 33: 19-35.

Bowerman, B.L. and R.T. O'Connell, 1990. Linear Statistical Models: An Applied Approach. 2nd Edn., PWS-Kent Pub. Co., New York, USA., ISBN: 9780534917968, Pages: 1024.

Brislin, R.W., 1970. Back-translation for cross-cultural research. J. Cross Cult. Psychol., 1: 185-216.

Bysted, R., 2013. Innovative employee behaviour: The moderating effects of mental involvement and job satisfaction on contextual variables. Eur. J. Innovation Manage., 16: 268-284.

Cable, D.M. and D.S. DeRue, 2002. The convergent and discriminant validity of subjective fit perceptions. J. Applied Psychol., 87: 875-884.

Cai, W., E.I. Lysova, S.N. Khapova and B.A.G. Bossink, 2018. Does entrepreneurial leadership foster creativity among employees and teams? The mediating role of creative efficacy beliefs. J. Bus. Psychol., 1: 1-15.

Carter, M.Z., A.A. Armenakis, H.S. Feild and K.W. Mossholder, 2013. Transformational leadership, relationship quality and employee performance during continuous incremental organizational change. J. Organizational Behav., 34: 942-958.

Chen, A.S.Y. and Y.H. Hou, 2016. The effects of ethical leadership, voice behavior and climates for innovation on creativity: A moderated mediation examination. Leadersh. Q., 27: 1-13.

Chen, J., W.S. Leung and K.P. Evans, 2016a. Are employee-friendly workplaces conducive to innovation?. J. Corporate Finance, 40: 61-79.

Chen, J.S., D. Kerr, C.Y. Chou and C. Ang, 2017. Business co-creation for service innovation in the hospitality and tourism industry. Intl. J. Contemp. Hospitality Manage., 29: 1522-1540. 
Chen, T., F. Li and K. Leung, 2016b. When does supervisor support encourage innovative behavior? Opposite moderating effects of general self-efficacy and internal locus of control. Personnel Psychol., 69: 123-158.

Chen, Y.R., X.P. Chen and R. Portnoy, 2009. To whom do positive norm and negative norm of reciprocity apply? Effects of inequitable offer, relationship and relational-self orientation. J. Exp. Social Psychol., 45: 24-34.

Chenhall, R.H. and K. Langfield-Smith, 2003. Performance measurement and reward systems, trust and strategic change. J. Manage. Accounting Res., 15: 117-143.

Chenhall, R.H., 2005. Integrative strategic performance measurement systems, strategic alignment of manufacturing, learning and strategic outcomes: An exploratory study. Accounting Organizations Soc., 30: $395-433$.

Chin, W.W., 1998a. Commentary: Issues and opinion on structural equation modeling. MIS Q., 22: 7-16.

Chin, W.W., 1998b. The partial least squares approach to structural equation modeling. Modern Methods Bus. Res., 295: 295-336.

Cohen, J., 1988. Statistical Power Analysis for the Behavioral Sciences. 2nd Edn., Lawrence Erlbaum, Hillsdale, New Jersey, USA., ISBN: 0-8058-6283-5, Pages: 128 .

Colquitt, J.A., B.A. Scott and J.A. LePine, 2007. Trust, trustworthiness and trust propensity: A meta-analytic test of their unique relationships with risk taking and job performance. J. Appl. Psychol., 92: 909-927.

Cooper, S., R. Cant, C. Connell, L. Sims and J.E. Porter et al., 2016. Measuring teamwork performance: Validity testing of the Team Emergency Assessment Measure (TEAM) with clinical resuscitation teams. Resuscitation, 101: 97-101.

Cropanzano, R., C.A. Prehar and P.Y. Chen, 2002. Using social exchange theory to distinguish procedural from interactional justice. Group Organiz. Manage., 27: 324-351.

Dansereau, F., G. Graen and W.J. Haga, 1975. A vertical dyad linkage approach to leadership within formal organizations: A longitudinal investigation of the role making process. Organizational Behav. Hum. Perform., 13: 46-78.

DeConinck, J.B. and J.T. Johnson, 2009. The effects of perceived supervisor support, perceived organizational support and organizational justice on turnover among salespeople. J. Pers. Selling Sales Manage., 29: 333-350.
DeConinck, J.B., 2010. The effect of organizational justice, perceived organizational support and perceived supervisor support on marketing employees' level of trust. J. Bus. Res., 63: 1349-1355.

Dhar, R.L., 2016. Ethical leadership and its impact on service innovative behavior: The role of LMX and job autonomy. Tourism Manage., 57: 139-148.

Dietz, J., S.D. Pugh and J.W. Wiley, 2004. Service climate effects on customer attitudes: An examination of boundary conditions. Acad. Manage. J., 47: 81-92.

Dirks, K.T. and D.L. Ferrin, 2002. Trust in leadership: Meta-analytic findings and implications for research and practice. J. Applied Psychol., 87: 611-628.

Donate, M.J. and J.D.S. de Pablo, 2015. The role of knowledge-oriented leadership in knowledge management practices and innovation. J. Bus. Res., 68: $360-370$.

Dong, Y., H. Liao, A. Chuang, J. Zhou and E.M. Campbell, 2015. Fostering employee service creativity: Joint effects of customer empowering behaviors and supervisory empowering leadership. J. Appl. Psychol., 100: 1364-1380.

Eid, R. and S. Elbanna, 2018. A triangulation study to assess the perceived city image in the Arab middle east context: The case of Al-Ain in the UAE. Tourism Plann. Dev., 15: 118-133.

Elenkov, D.S. and I.M. Manev, 2005. Top management leadership and influence on innovation: The role of sociocultural context. J. Manage., 31: 381-402.

Epitropaki, O., I. Kapoutsis, B.P. Ellen III, G.R. Ferris, $\mathrm{K}$. Drivas et al., 2016. Navigating uneven terrain: The roles of political skill and LMX differentiation in prediction of work relationship quality and work outcomes. J. Organizational Behav., 37: 1078-1103.

Erdogan, B. and J. Enders, 2007. Support from the top: Supervisors perceived organizational support as a moderator of leader-member exchange to satisfaction and performance relationships. J. Appl. Psychol., 92: 321-330.

Fornell, C. and D.F. Larcker, 1981. Evaluating structural equation models with unobservable variables and measurement error. J. Market. Res., 18: 39-50.

Fornell, C. and J. Cha, 1994. Partial Least Squares. In: Advanced Methods in Marketing Research, Bagozzi, R.P. (Ed.). Wiley, Hoboken, New Jersey, USA., ISBN:9781557865496, pp: 52-78.

Garg, S. and R.L. Dhar, 2014. Effects of stress, LMX and perceived organizational support on service quality: Mediating effects of organizational commitment. J. Hospitality, Tourism, Manage., 21: 64-75. 
Gefen, D. and E.E. Rigdon, 2011. An update and extension to SEM guidelines for administrative and social science research. MIS. Q., 35: 1-7.

Gefen, D., D.W. Straub and M.C. Boudreau, 2000. Structural equation modeling and regression: Guidelines for research practice. Commun. Assoc. Inform. Syst., 4: 1-77.

Gold, A.H., A. Malhotra and A.H. Segars, 2001. Knowledge management: An organizational capabilities perspective. J. Manage. Inform. Syst., 18: 185-214.

Graen, E.B. and T.A. Scandura, 1987. Toward a psychology of dyadic organizing. Res. Org. Behav., 9: 174-208.

Graen, G.B. and M. Uhl-Bien, 1995. Relationship-based approach to leadership: Development of LeaderMember Exchange (LMX) theory of leadership over 25 years: Applying a multi-level multi-domain perspective. Leadersh. Q., 6: 219-247.

Hair, J.F., W.C. Black, B.J. Babin and R.E. Anderson, 2010. Multivariate Data Analysis: A Global Perspective. 7th Edn., Pearson Education Inc., Upper Saddle River, NJ., USA., ISBN-13: 9780135153093 , Pages: 800.

Hair, Jr., J.F., G.T.M. Hult, C.M. Ringle and M. Sarstedt, 2017. A Primer on Partial Least Squares Structural Equation Modeling (PLS-SEM). 2nd Edn., Sage Publisher, Thousand Oaks, California.

Hammond, M.M., N.L. Neff, J.L. Farr, A.R. Schwall and X. Zhao, 2011. Predictors of individual-level innovation at work: A meta-analysis. Psychol. Aesthetics Creativity Arts, 5: 90-105.

Henseler, J., C.M. Ringle and M. Sarstedt, 2015. A new criterion for assessing discriminant validity in variance-based structural equation modeling. $\mathrm{J}$. Acad. Marketing Sci., 43: 115-135.

Hoch, J.E., W.H. Bommer, J.H. Dulebohn and D. Wu, 2018. Do ethical, authentic and servant leadership explain variance above and beyond transformational leadership? A meta-analysis. J. Manage., 44: 501-529.

Hollander, E.P., 1978. Leadership Dynamics: A Practical Guide to Effective Relationships. The Free Press, New York, Pages: 228.

Homans, G.C., 1958. Social behavior as exchange. Am. J. Sociol., 63: 597-606.

Hon, A.H., 2011. Enhancing employee creativity in the Chinese context: The mediating role of employee self-concordance. Intl J. Hospitality Manage., 30: 375-384.

Hon, A.H.Y., 2010. Shaping environments conductive to creativity: The role of intrinsic motivation. Cornell Hospitality Q., 53: 53-64.
Howell, J.M. and K.E. Hall-Merenda, 1999. The ties that bind: The impact of leader-member exchange, transformational and transactional leadership and distance on predicting follower performance. J. Applied Psychol., 84: 680-694.

Huang, X., J. Iun, A. Liu and Y. Gong, 2010. Does participative leadership enhance work performance by inducing empowerment or trust? The differential effects on managerial and non-managerial subordinates. J. Organiz. Behav., 31: 122-143.

Index, G.I., 2016. Government institutions effectiveness: Yemen versus Arab countries: Rank among 143 countries. INSEAD and the World Intellectual Property Organization (WIPO), Cornell University, Ithaca, New York, USA.

Janssen, O. and N.W. van Yperen, 2004. Employees' goal orientations, the quality of leader-member exchange and the outcomes of job performance and job satisfaction. Acad. Manage. J., 47: 368-384.

Joo, B.K., 2010. Organizational commitment for knowledge workers: The roles of perceived organizational learning culture, leader-member exchange quality and turnover intention. Hum. Resour. Dev. Q., 21: 69-85.

Jung, D.I., C. Chow and A. Wu, 2003. The role of transformational leadership in enhancing organizational innovation: Hypotheses and some preliminary findings. Leadersh. Q., 14: 525-544.

Kang, J.H., J.G. Matusik, T. Y. Kim and J.M. Phillips, 2016. Interactive effects of multiple organizational climates on employee innovative behavior in entrepreneurial firms: A cross-level investigation. J. Bus. Venturing, 31: $628-642$.

Kannan, V.R. and K.C. Tan, 2005. Just in time, total quality management and supply chain management: Understanding their linkages and impact on business performance. Omega, 33: 153-162.

Khalefa, G.S.A., 2015. Ethnic restaurants meal experience: Egyptian customers perceptions. Intl. J. Heritage Tourism Hospitality, 9: 92-112.

Khalifa, G.S. and M.A. Abou-Shouk, 2014. Investigating the success factors of hotel websites: The case of Egyptian hotels. Asia Pac. J. Innovation Hospitality Tourism, 3: 131-151.

Khalifa, G.S.A. and M. Hewedi, 2016. Factors affecting hotel website purchasing intentions: Evidence from Egypt. J. Faculty Tourism Hotels, Fayoum Univ., 8: 50-69.

Khalifa, G.S.A. and N.M. Fawzy, 2017. Measuring E-service quality (Expectation Vs. Perception) from travel agencies perspective: An empirical study on egyptian hotel websites. Intl. J. Recent Trends Bus. Tourism, 1: 36-48. 
Khaola, P. and D. Coldwell, 2019. Explaining how leadership and justice influence employee innovative behaviours. Eur. J. Innovation Manage., 22: $193-212$.

Kline, R.B., 2010. Principles and Practice of Structural Equation Modeling. 3rd Edn., The Guilford Press, New York, USA., ISBN-13: 9781606238769, Pages: 427.

Konovsky, M.A. and S.D. Pugh, 1994. Citizenship behavior and social exchange. Acad. Manage. J., 37: 656-669.

Krejcie, R.V. and D.W. Morgan, 1970. Determining sample size for research activities. Educ. Psychol. Meas., 30: 607-610.

Lee, B.C., J.O. Yoon and I. Lee, 2009. Learner's acceptance of e-learning in South Korea: Theories and results. Comput. Educ., 53: 1320-1329.

Levitt, T., 2002. Creativity is not enough. Harv. Bus. Rev., 80: $137-144$.

$\mathrm{Li}, \mathrm{C}$. and K. Shi, 2008. The structure and measurement of transformational leadership in China. Front. Bus. Res. China, 2: 571-590.

Li, J.J., W.G. Kim and X.R. Zhao, 2017. Multilevel model of management support and casino employee turnover intention. Tourism Manage., 59: 193-204.

Liao, H. and A. Chuang, 2007. Transforming service employees and climate: A multilevel, multisource examination of transformational leadership in building long-term service relationships. J. Applied Psychol., 92: 1006-1019.

Liaw, Y.J., N.W. Chi and A. Chuang, 2010. Examining the mechanisms linking transformational leadership, employee customer orientation, and service performance: The mediating roles of perceived supervisor and coworker support. J. Bus. Psychol., 25: 477-492.

Lin, R.J., R.H. Chen and K.K.S. Chiu, 2010. Customer relationship management and innovation capability: An empirical study. Ind. Manage. Data Sys., 110: 111-133.

Liu, D., K. Jiang, C.E. Shalley, S. Keem and J. Zhou, 2016. Motivational mechanisms of employee creativity: A meta-analytic examination and theoretical extension of the creativity literature. Organizational Behave. Hum. Decis. Processes, 137: 236-263.

Luo, Y., 2005. Corporate governance and accountability in multinational enterprises: Concepts and agenda. J. Intl. Manage., 11: 1-18.

Makri, M. and T.A. Scandura, 2010. Exploring the effects of creative CEO leadership on innovation in high-technology firms. Leadership Q., 21: 75-88.
Martin, R., Y. Guillaume, G. Thomas, A. Lee and O. Epitropaki, 2016. Leader-member exchange (LMX) and performance: A meta-analytic review. Personnel Psychol., 69: 67-121.

Masterson, S.S., K. Lewis, B.M. Goldman and M.S. Taylor, 2000. Integrating justice and social exchange: The differing effects of fair procedures and treatment on work relationships. Acad. Manage. J., 43: 738-748.

Mayfield, M. and J. Mayfield, 2009. The role of leader-follower relationships in leader communication: A test using the LMX and motivating language models. J. Bus. Inq., 8: 65-82.

McAllister, D.J., 1995. Affect-and cognition-based trust as foundations for interpersonal cooperation in organizations. Acad. Manage. J., 38: 24-59.

Mohamud, S.S., G.S.A. Khalifa, A.E. Abuelhassan and S. Kaliyamoorthy, 2017. Investigating the antecedents of coffee shop customers' behavioral intentions in Kuala Lumpur. Intl. J. Recent Trends Bus. Tourism, 1: 1-14.

Montes, F.J.L., A.R. Moreno and V.G. Morales, 2005. Influence of support leadership and teamwork cohesion on organizational learning, innovation and performance: An empirical examination. Technovation, 25: 1159-1172.

Myers, R.H., 1990. Classical and Modern Regression with Applications. 2nd Edn., Duxbury, Washington.

Nunnally, J.C. and I.H. Bernstein, 1994. Psychometric Theory. 3rd Edn., McGraw-Hill, New York, USA.

O'Brien, R.M., 2007. A caution regarding rules of thumb for variance inflation factors. Qual. Quantity, 41: 673-690.

Paulus, P.B. and H.C. Yang, 2000. Idea generation in groups: A basis for creativity in organizations. Organizational Behav. Hum. Decis. Processes, 82: 76-87.

Pillai, R., T.A. Scandura and E.A. Williams, 1999. Leadership and organizational justice: Similarities and differences across cultures. J. Int. Bus. Stud., 30: 763-779.

Qoura, O. and G.S.A. Khalifa, 2016. The impact of reputation management on hotel image among internal customers: The case of egyptian hotels. Intl. J. Heritage Tourism Hospitality, 7: 261-274.

Radzi, C.W.J.W.M., H. Hui, H.S. Jenatabadi, F.A. Kasim and S. Radu, 2013. The relationship among transformational leadership, organizational learning and organizational innovation: A case study in asian manufacturing food industry. Asian J. Empirical Res., 3: 1051-1060. 
Rao, M.S., 2016. Collaborate to build effective teams to achieve organizational excellence and effectiveness. Ind. Commer. Training, 48: 24-28.

Restubog, S.L.D., P. Bordia, R.L. Tang and S.A. Krebs, 2010. Investigating the moderating effects of leader-member exchange in the psychological contract breach-employee performance relationship: A test of two competing perspectives. Br. J. Manage., 21: 422-437.

Ringle, C.M. and M. Sarstedt, 2016. Gain more insight from your PLS-SEM results: The importanceperformance map analysis. Ind. Manage. Data Syst., 116: $1865-1886$.

Ringle, C.M., S. Wende and J.M. Becker, 2015. SmartPLS 3. SmartPLS GmbH, Bonningstedt, Germany.

Robinson, R.N. and L.G. Beesley, 2010. Linkages between creativity and intention to quit: An occupational study of chefs. Tourism Manage., 31: 765-776.

Scandura, T.A., G.B. Graen and M.A. Novak, 1986. When managers decide not to decide autocratically: An investigation of leader-member exchange and decision influence. J. Appl. Psychol., 71: 579-584.

Schneider, B., E.G. Godfrey, S.C. Hayes, M. Huang and B.C. Lim et al., 2002. The human side of strategy: Employee experiences of strategic alignment in a service organization. Organizational Dyn., 32: 122-141.

Schneider, B., J.K. Wheeler and J.F. Cox, 1992. A passion for service: Using content analysis to explicate service climate themes. J. Appl. Psychol., 77: 705-716.

Schneider, B., M.G. Ehrhart, D.M. Mayer, J.L. Saltz and K. Niles-Jolly, 2005. Understanding organization-customer links in service settings. Acad. Manage. J., 48: 1017-1032.

Schneider, S.K. and W.M. George, 2011. Servant leadership versus transformational leadership in voluntary service organizations. Leadersh. Organiz. Dev. J., 32: 60-77.

Schriesheim, C.A., L.L. Neider and T.A. Scandura, 1998. Delegation and leader-member exchange: Main effects, moderators and measurement issues. Acad. Manage. J., 41: 298-318.

Schumacker, R.E. and R.G. Lomax, 2004. A beginner's Guide to Structural Equation Model. 2nd Edn., Lawrence Erlbaum Associates, Mahwah, New YorK.

Scott, S.G. and R.A. Bruce, 1994. Determinants of innovative behavior: A path model of individual innovation in the workplace. Acad. Manage. J., 37: 580-607.
Sekiguchi, T., J.P. Burton and C.J. Sablynski, 2008. The role of job embeddedness on employee performance: The interactive effects with leader-member exchange and organization-based self-esteem. Personnel Psychol., 61: 761-792.

Shalley, C.E. and L.L. Gilson, 2004. What leaders need to know: A review of social and contextual factors that can foster or hinder creativity. Leadership Q., 15: 33-53.

Shalley, C.E., J. Zhou and G.R. Oldham, 2004. The effects of personal and contextual characteristics on creativity: Where should we go from here? J. Manage., 30: 933-958.

Sosik, J.J., S.S. Kahai and B.J. Avolio, 1998. Transformational leadership and dimensions of creativity: Motivating idea generation in computer-mediated groups. Creativity Res. J., 11: 111-121 .

Sullivan, G.M. and R. Feinn, 2012. Using effect size-or why the $\mathrm{P}$ value is not enough. J. Graduate Med. Educ., 4: 279-282.

Tabachnick, B.G. and L.S. Fidell, 2012. Using Multivariate Statistics. 6th Edn., Pearson Education, Boston, MA., ISBN-13: 9780205849574 , Pages: 983.

Tan, H.H. and C.S.F. Tan, 2000. Toward the differentiation of trust in supervisor and trust in organization. Genet. Soc. Gen. Psychol. Monogr., 126: 241-260.

Tastan, S.B. and S.M.M. Davoudi, 2015. An examination of the relationship between leader-member exchange and innovative work behavior with the moderating role of trust in leader: A study in the Turkish context. Procedia Social Behav. Sci., 181: 23-32.

Volmer, J., D. Spurk and C. Niessen, 2012. Leader-member exchange (LMX), job autonomy and creative work involvement. Leadersh. Q., 23: 456-465.

Walumbwa, F.O., C.A. Hartnell and E. Misati, 2017. Does ethical leadership enhance group learning behavior? Examining the mediating influence of group ethical conduct, justice climate and peer justice. J. Bus. Res., 72: 14-23.

Walumbwa, F.O., D.M. Mayer, P. Wang, H. Wang and $\mathrm{K}$. Workman et al., 2011. Linking ethical leadership to employee performance: The roles of leader-member exchange, self-efficacy and organizational identification. Organizational Behav. Hum. Decis. Processes, 115: 204-213.

Wang, C.J., H.T. Tsai and M.T. Tsai, 2014. Linking transformational leadership and employee creativity in the hospitality industry: The influences of creative role identity, creative self-efficacy and job complexity. Tourism Manage., 40: 79-89. 
Wang, H., K.S. Law, R.D. Hackett, D. Wang and Z.X. Chen, 2005. Leader-member exchange as a mediator of the relationship between transformational leadership and follower's performance and organizational citizenship behavior. Acad. Manage. J., 48: 420-432.

Wang, W.T. and C.P. Hsiao, 2014. The influences of knowledge exchange on organizational C-Commerce success and crisis readiness: The case of the crisis of an automobile manufacturing and merchandising group. Decis. Support Syst., 68: 1-14.

Wang, X.H., Y. Fang, I. Qureshi and O. Janssen, 2015. Understanding employee innovative behavior: Integrating the social network and leader-member exchange perspectives. J. Organiz. Behav., 36: 403-420.

Wayne, S.J., L.M. Shore and R.C. Liden, 1997. Perceived organizational support and leader-member exchange: A social exchange perspective. Acad. Manage. J., 40: 82-111.

Weng, R.H., W.P. Chen, C.Y. Huang, C.H. Hung and C.T. Hsu, 2016. Can nurse innovation improve customer perception of service quality and experience? J. Clin. Nurs., 25: 1950-1961.

Werts, C.E., R.L. Linn and K.G. Joreskog, 1974. Intraclass reliability estimates: Testing structural assumptions. Educ. Psychol. Meas., 34: 25-33.

Wisse, B., D.P. Barelds and E.F. Rietzschel, 2015. How innovative is your employee? The role of employee and supervisor Dark Triad personality traits in supervisor perceptions of employee innovative behavior. Personality Individual Differences, 82: 158-162.
Wong, Y.T., C.S. Wong and H.Y. Ngo, 2002. Loyalty to supervisor and trust in supervisor of workers in Chinese joint ventures: A test of two competing models. Intl. J. Hum. Resour. Manage., 13: 883-900.

Wong, Y.T., H.Y. Ngo and C.S. Wong, 2006. Perceived organizational justice, trust and OCB: A study of Chinese workers in joint ventures and state-owned enterprises. J. World Bus., 41: 344-355.

Wu, M., X. Huang, C. Li and W. Liu, 2012. Perceived interactional justice and trust-in-supervisor as mediators for paternalistic leadership. Manage. Organiz. Rev., 8: 97-122.

Xerri, M., 2013. Workplace relationships and the innovative behaviour of nursing employees: A social exchange perspective. Asia Pac. J. Hum. Resour., 51: 103-123.

Yang, J. and K.W. Mossholder, 2010. Examining the effects of trust in leaders: A bases-and-foci approach. Leadership Q., 21: 50-63.

Yang, J., K.W. Mossholder and T.K. Peng, 2009. Supervisory procedural justice effects: The mediating roles of cognitive and affective trust. Leadership Q., 20: 143-154.

Yukl, G. and P.P. Fu, 1999. Determinants of delegation and consultation by managers. J. Organiz. Behav. Intl. J. Ind. Occup. Organ. Psychol. Behav., 20: 219-232.

Zhang, Z., M.O. Wang and J. Shi, 2012. Leader-follower congruence in proactive personality and work outcomes: The mediating role of leader-member exchange. Acad. Manage. J., 55: 111-130. 